\title{
Kontribusi Pelatihan Dasar Fungsional terhadap Peningkatan Kompetensi Penyuluh Pertanian di Provinsi Jambi
}

\section{Contribution of Functional Basic Training for Improving the Competency of Agricultural Extensions in Jambi Province}

Lindung

Balai Pelatihan Pertanian Jambi, Jl. Jambi-Palembang KM. 16. Kab. Muaro Jambi, Jambi, Indonesia

*email: lindungjuni@gmail.com

\begin{tabular}{|c|c|}
\hline I N FO A R T I K EL L & A B S T RA K \\
\hline $\begin{array}{l}\text { Sejarah artikel: } \\
\text { Dikirim 5 Februari } 2021 \\
\text { Diterima } 10 \text { September } \\
2021 \\
\text { Terbit } 5 \text { Oktober } 2021\end{array}$ & $\begin{array}{l}\text { Pelatihan merupakan salah satu cara dalam meningkatkan kompetensi, juga } \\
\text { indikator keberhasilan instansi penyelenggara pelatihan seperti Balai Pelatihan } \\
\text { Pertanian (BPP) Jambi. Berdasarkan hal tersebut, tujuan peneliitian ini (1) } \\
\text { menganalisis peningkatan kompetensi penyuluh pertanian melalui pelatihan dasar } \\
\text { fungsional di BPP Jambi, (2) menganalisis faktor-faktor yang mempengaruhi hasil }\end{array}$ \\
\hline $\begin{array}{l}\text { Kata kunci: } \\
\text { Kompetensi } \\
\text { Pelatihan } \\
\text { Penyuluh pertanian }\end{array}$ & $\begin{array}{l}\text { ujian komprehensif sebagai indikator akhir peningkatan kompetensi. Penelitian } \\
\text { menggunakan data primer berupa data pre test dan post test, dailymood, perilaku, } \\
\text { kepuasan berlatih, dan hasil ujian komprehensif peserta pelatihan. Responden } \\
\text { ditentukan dengan teknik random sampling sebanyak } 93 \text { orang dari } 183 \text { orang } \\
\text { penyuluh pertanian asal Provinsi Jambi yang mengikuti pelatihan dasar fungsional } \\
\text { tahun } 2018 \text { di BPP Jambi. Analisis normalitas, uji t sampel berpasangan, dan regresi }\end{array}$ \\
\hline $\begin{array}{l}\text { Keywords: } \\
\text { Competence } \\
\text { Training } \\
\text { Agricultural extension }\end{array}$ & $\begin{array}{l}\text { linear digunakan untuk menjawab tujuan penelitian. Hasil uji normalitas } \\
\text { menunjukkan data menyebar normal. Hasil uji t mengindikasikan bahwa terdapat } \\
\text { perbedaan nyata antara nilai pre test dan post test, perbedaan nyata antara nilai } \\
\text { perilaku awal, tengah, dan akhir, antara dailymood, kepuasan berlatih, perilaku, } \\
\text { post test, dan ujian komprehensif. Hasil uji F menunjukan secara bersama faktor- } \\
\text { faktor dailymood, perilaku, dan kepuasan berlatih berpengaruh terhadap ujian } \\
\text { komprehensif. Secara parsial dari ujit t, hanya faktor perilaku yang berpengaruh } \\
\text { nyata. Hal ini menunjukkan bahwa pelatihan mampu memberikan kontribusi dalam } \\
\text { meningkatkan kompetensi penyuluh pertanian. Berdasarkan hasil penelitian } \\
\text { diperlukan lagi penelitian lanjutan mengenai dampak pelatihan terhadap motivasi } \\
\text { dan kinerja dari penyuluh pertanian. }\end{array}$ \\
\hline
\end{tabular}

\section{A B S T R A C T}

Training is one way of increasing competence, as well as an indicator of the success of training providers such as the Jambi Agricultural Training Center (BPP Jambi. Based on this, the objectives of this research are (1) to analyze the improvement of agricultural instructor competence through basic functional training at BPP Jambi, (2) to analyze the factors that affect the results of comprehensive examinations as a final indicator of competency improvement. The study used

Kutipan format APA: Lindung. (2021). Kontribusi Pelatihan Dasar Fungsional terhadap Peningkatan Kompetensi Penyuluh Pertanian di Provinsi Jambi. AgriHumanis: Journal of Agriculture and Human Resource Development Studies, 2(2), 71-80. primary data in the form of pre-test and post-test data, dailymood, behavior, practice satisfaction, and the results of the training participants' comprehensive exams. Respondents were determined by random sampling technique as many as 93 people from 183 agricultural extension workers from Jambi Province who attended basic functional training in 2018 at BPP Jambi. Analysis of normality, paired sample t test, and linear regression were used to answer the research objectives. The results of the normality test show that the data is spread normally. The t test results indicate that there is a significant difference between the pre-test and post-test scores, the real differences between the initial, middle, and final behavior scores, between dailymood, practice satisfaction, behavior, post test, and comprehensive exams. he results of the $F$ test show together the factors of dailymood, behavior, and practice satisfaction have an effect on the comprehensive exam. Partially from the t test, only the behavioral factors have a significant effect. This shows that the training is able to contribute in increasing the competence of 
agricultural instructors. Based on the research results, further research is needed regarding the impact of training on the motivation and performance of agricultural extension agents.

\section{PENDAHULUAN}

Sumberdaya manusia merupakan faktor yang paling penting dan paling menentukan dalam setiap organisasi. Ia merupakan penentu jalan-tidaknya ataupun maju mundurnya sebuah organisasi. Dalam hal ini sumberdaya manusia merupakan human capital dan intellectual capital yang akan menentukan efektivitas dari sumberdaya lainnya yang dimiliki oleh suatu organisasi. Sumber daya manusia harus dimanajemen sedemikian rupa sehingga pemanfaatannya lebih berhasil guna. Pattanayak (2002) menyatakan human resources managament encoupasses those activities design to provide motivate and coordinate the human resources of an organization. Pernyataan tersebut mengandung maksud bahwa sumber daya manusia meliputi berbagai aktivitas yang didesain untuk memberi kesempatan, memotivasi, dan mengkoordinasikan sumber daya manusia dalam suatu organisasi. Mengingat pentingnya sumberdaya manusia maka konsekuensinya harus ada pengembangan sumberdaya manusia itu dengan tujuan peningkatan kompetensi yang dimiliki agar berguna bagi tujuan organisasinya.

Kompetensi pekerja yang merupakan salah satu modal sumberdaya manusia adalah kekuatan aktual yang bersumber dari pengetahuan, keterampilan, dan sikap kerja yang dipersyaratkan untuk melakukan tugas pekerjaannya, yang dibutuhkan organisasi tempat seseorang bekerja. Kompetensi akan mendorong seseorang untuk memiliki kinerja terbaik sehingga dapat sukses dalam organisasi (Sudarmanto, 2009). Pencer et al, (1990) dalam buku Competency Assessment Methods, Hay/McBer Research Press, New York, menggambarkan sebagaimana dikutip oleh Dharma (2002), kompetensi merupakan karakteristik yang mendasari seseorang dan berkaitan dengan efektivitas kinerja individu dalam pekerjaannya. Dharma menjelaskan ada lima karakteristik pembentuk kompetensi, yaitu watak, motif, konsep diri, pengetahuan, dan keterampilan. Kompetensi turut menentukan kinerja seseorang, dimana kinerja merupakan ungkapan kemampuan yang didasari oleh pengetahuan, sikap, ketrampilan, dan motivasi dalam menghasilkan sesuatu (Yusuf, 2008).

Peraturan Menteri Negara Pendayagunaan Aparatur Negara nomor 02 tahun memberikan batasan Penyuluh Pertanian sebagai jabatan fungsional dengan ruang lingkup tugas, tanggung jawab, dan wewenang penyuluhan pertanian yang diduduki oleh Pegawai Negeri Sipil yang diberi hak serta kewajiban secara penuh oleh pejabat yang berwenang. Penyuluh pertanian adalah agen perubahan di bidang pertanian yang dituntut melakukan proses alih kompetensi dalam pemberdayaan masyarakat tani untuk mencari, menciptakan, menggunakan berbagai akses yang terkait produksi, penanganan produksi dan pemasaran produk pertanian. Rivera \& Qamar (2003) menjelaskan bahwa peran penyuluh adalah multidisiplin. Abugu et al, (2013) menjelaskan bahwa peranan penyuluh dibutuhkan untuk membantu petani dalam mendapatkan sumber input pertanian dan membangun pasar yang layak bagi petani. Mengingat peran dan ruang lingkup tugas penyuluh pertanian maka penyuluh pertanian dituntut memiliki kompetensi yang tinggi sehingga kinerja penyuluh pertanian memberikan hasil nyata bagi petani. Upaya peningkatan kompetensi penyuluh pertanian salah satunya melalui pelatihan dasar fungsionalnya yaitu pelatihan yang memuat materi tugas pokok penyuluh pertanian. Tugas pokok Penyuluh Pertanian adalah melakukan kegiatan persiapan penyuluhan pertanian, pelaksanaan penyuluhan pertanian evaluasi dan pelaporan, serta pengembangan penyuluhan pertanian. Penyuluh pertanian harus memenuhi persyaratan mengikuti diklat dasar fungsional di bidang pertanian.

Melaui pelatihan dasar fungsional diharapkan seorang penyuluh yang memiliki kompetensi dasar dalam melaksanakan tugas pokok dan fungsinya serta mampu menunjukan kinerja yang baik. Bahua (2010) mendefinisikan kinerja merupakan aksi atau prilaku individu yang berupa bagian dari fungsi kerja aktualnya dalam suatu organisasi. Lailani \& Jahi (2006) mengartikan kinerja penyuluh bahwa kinerja merupakan fungsi dari karakteristik individu dan kinerja penyuluh pertanian merupakan pengaruh dari situasional. Dalam hal ini kinerja penyuluh pertanian merupakan sebuah prestasi kerja yang dicapai seorang penyuluh pertanian berdasarkan tugas pokok dan fungsinya baik melalui individu maupun organisasinya.

Aktivitas penyuluhan pertanian di Indonesia menyebar di seluruh daerah termasuk di Provinsi Jambi. Berdasarkan kontribusi ekonomi, pertanian merupakan sektor dominan dipandang dari keterlibatan tenaga kerja dan sumbangan pendapatan ekonomi daerah, hal ini dikarenakan daerah ini 
secara geografis memiliki potensi pengembangan pertanian dengan cakupan usaha yang luas, meliputi usaha sektor perkebunan (penekanan kelapa sawit, karet, dan kopi, kayu manis), usaha sector tanaman pangan (penekanan padi, palawija dan umbi-umbian), serta usahan sekktor hortikultura (khususnya sayuran dan buah-buahan). Pembangunan sektor pertanian di Jambi menekankan pada sistem hulu dan hilir yang ditargetkan dapat menunjang pertumbuhan ekonomi, pilihan lapangan kerja, dan meningkatkan kesejahteraan masyarakat, serta untuk keberlanjutan kemandirian pangan. Jumlah penyuluh pertanian di Provinsi Jambi tahun 2018 mencapai 1.733 orang yang berstatus PNS, penyuluh THL-TBPP, penyuluh honor daerah, dan penyuluh swadaya (Balai Pelatihan Pertanian Jambi, 2019).

Penyuluh pertanian menjalankan tugas pokoknya yang meliputi merencanakan, melaksanakan, mengevaluasi, melaporkan dan mengembangkan penyuluhan pertanian selalu menghadapi permasalahan yang selalu bergerak dinamis, karena sasaran penyuluhan, yaitu petani dan keluarganya dimana antar petani memiliki penciri yang berbeda. Penyuluh pertanian perlu memiliki kompetensi yang digunakan untuk pendekatan yang berbeda untuk sasarannya, baik itu materi, metode, maupun media penyuluhan. Kompetensi dasar penyuluh dapat diperoleh melalui pelatihan dasar fungsional. Pertanyaan yang muncul adalah apakah pelatihan dasar fungsional memberikan kontribusi terhadap peningkatan kompetensi penyuluh pertanian yang mengikuti pelatihan dasar fungsional, serta apakah ada hubungan antar variabel-variabel penilaian pelatihan dasar fungsional dengan peningkatan kompetensi penyuluh pertanian.

Berdasarkan hal tersebut penelitian ini bertujuan untuk (1) menganalisis kontribusi pelatihan dasar fungsional terhadap peningkatan kompetensi peserta pelatihan (2) Menganalisis variabel-variabel evaluasi yang digunakan Balai Pelatihan Pertanian Jambi selama pelatihan dalam meningkatkan kompetensi peserta pelatihan.

\section{METODE}

\subsection{Pengumpulan dan Analisis Data}

Penelitian dilakukan pada bulan April tahun 2020 s/d bulan Oktober tahun 2020 di Balai Pelatihan Pertanian (BPP) Jambi yang beralamat Desa Pondok Meja, Kecamatan Mestong, Kabupaten Muaro Jambi, Provinsi Jambi. Subjek penelitian ini adalah penyuluh pertanian yang mengikuti pelatihan dasar fungsional pada tahun 2018 di BPP Jambi, dimana jumlah penyuluh asal Provinsi Jambi yang mengikuti pelatihan sebanyak 138 orang, yang dijadikan sampel penelitian sebanyak 93 orang.

Data dikumpulkan dari sejumlah instrumen evaluasi dengan indikator-indikator pengukuran yang sesuai dengan ketentuan penyelenggara pelatihan dasar fungsional, yaitu: 1. Pret test dan post test adalah kegiatan menguji tingkatan pemahaman peserta pelatihan terhadap materi yang akan disampaikan, yang dilakukan sebelum dan sesudah kegiatan pengajaran diberikan dalam bentuk pertanyaan tertulis. 2 . Daily mood (perasaan harian) adalah perasaan pribadi responden sebagai peserta terhadap pelaksanaan pelatihan. 3. Penilaian terhadap perilaku adalah akumulasi tindakan peserta selama pelatihan yang penilaiannya dilakukan oleh meliputi unsur disiplin, motivasi, kerjasama, prakarsa (ide, inisiatif), kepemimpinan (ketegasan, keberanian, konsistensi, komitmen, proaktif). 5. Kepuasan berlatih adalah penilaian peserta berdasarkan persepsinya selama mengikuti pelatihan atas pelayanan penyelenggara pelatihan, meliputi kepuasan pelayanan administrasi, pelayanan fasilitas pelatihan, dan kepuasan pelayanan widyaiswara. Pelayanan widyaiswara meliputi penguasan materi (pengetahuan, keterampilan, sikap), penguasaan metoda (kemampuan penyajian, berkomunikasi, kemampuan menjawab, nada dan suara, kerjasama), kemampuan menggunakan alat bantu (penggunaan sarana), penegakan disiplin (kehadiran, kerapihan berpakaian, sikap dan perilaku), dan tujuan pembelajaran (relevansi materi dengan indikator keberhasilan, pencapaian tujuan pembelajaran. 6. Ujian Komprehensif adalah kegiatan menguji peserta pelatihan terhadap keseluruhan materi yang telah diberikan selama pelatihan yang dilakukan oleh widyaiswara.

Semua data yang dianalisis dengan program SPSS 23, dimana variabel-variabel penelitian akan dianalisis dengan rincian sebagai berikut 1). Hubungan pret test dengan post test, 2). Hubungan perilaku awal, perilaku tengah, dan perilaku akhir, 3) Hubungan dailymood, kepuasan berlatih, perilaku post test dan ujian komprehensif, 4). Pengaruh dailymood, perilaku dan kepuasan terhadap hasil ujian komprehensif 
Metode analisis data adalah analisis deskriptif kuantitatif untuk menganalisis peningkatan kompetensi responden selama mengikuti pelatihan dasar fungsional, yaitu menggunakan uji t sampel berpasangan (t paired sample), yaitu untuk membandingkan rata-rata dua variabel untuk suatu grup sampel tunggal (meliputi kelompok pret test dan post test serta kelompok perilaku awal, tengah, dan akhir) dan menguji apakah selisih rata-rata tersebut bernilai nol. Rumus statistika uji t sampel berpasangan adalah:

$$
\mathrm{t}=\frac{\bar{x} D-\mu 0}{S D / \sqrt{n}}
$$

Keterangan:

$$
\begin{aligned}
& \mathrm{D}=\text { Selisih } \mathrm{x} 1 \text { dan } \mathrm{x} 2(\mathrm{x} 1-\mathrm{x} 2), \\
& \mathrm{n}=\text { Jumlah Sampel, } \bar{x}=\text { Rata-rata, } \\
& \mathrm{Sd}=\text { Standar deviasi } \mathrm{d}
\end{aligned}
$$

Untuk mengukur keeratan hubungan antar variabel-variabel dailymood, kepuasan berlatih, perilaku, post test, dan hasil ujian komprehensif digunakan analisis korelasi pearson. Alat analisis untuk melihat pengaruh antar variabel bebas terhadap variabel terikat hasil ujian komprehensif digunakan uji regresi linear berganda dengan persamaan sebagai berikut:

$$
Y=a+b 1 X 1+b 2 X 2
$$

Keterangan:

$\mathrm{Y}=$ variabel terikat

$\mathrm{X}=$ variael bebas

$\mathrm{a}=$ nilai konstan variabel terikat $(\mathrm{Y})$ apabila variabel $\mathrm{X}$ tidak berubah/tetap

$\mathrm{b}=$ koefisien arah regresi variabel $\mathrm{Y}$ atas variabel $\mathrm{X}$, yaitu besar perubahan pada nilai variabel $\mathrm{Y}$ yang disebabkan atau diakibatkan oleh perubahan pada variabel $\mathrm{X}$

\section{HASIL DAN PEMBAHASAN}

\subsection{Hubungan Pre Test dan Post Test}

Pelatihan merupakan rangkaian kegiatan yang disusun dan ditetapkan untuk transfer pengetahuan dan keterampilan yang dibutuhkan para peserta latihan untuk agar mampu melaksanakan pekerjaan mereka pada kondisi saat ini. Pelatihan dimaksudkan untuk menambah kompetensi melalui peningkatan pengetahuan, keterampilan dan sikap peserta Mondy dan Noe (2008). Salah satu penanda yang digunakan untuk mengetahui terjadinya peningkatan kompetensi diukur hasil jawaban responden pada saat melaksanakan pre test dan post test. Penilaian cara pre test dan post test adalah kegiatan evaluasi yang dilakukan oleh widyaiswara dengan tujuan mendapatkan informasi tentang kompetensi peserta, dimana peserta diberikan seperangkat pertanyaan atau pernyataan atau tugas tertentu dengan memiliki aturan atau jawaban yang dianggap benar.

Penilaian dengan prosedur pre test adalah suatu bentuk pertanyaan, yang diberikan widyaiswara kepada peserta sebelum memulai suatu pelajaran. Pre test diberikan dengan maksud untuk mengetahui apakah ada di antara peserta yang sudah mengetahui mengenai materi yang akan disampaikan. Sedangkan penilaian dengan Prosedur post test adalah bentuk pertanyaan yang diberikan setelah materi pelatihan telah disampaikan, dengan maksud apakah peserta sudah mengerti dan memahami mengenai materi yang diberikan pada pada pelatihan itu.

\begin{tabular}{|c|c|c|c|c|c|}
\hline & & Minimum & Maximum & Mean & Std.Deviation \\
\hline Pre test & 93 & 28,00 & 80,00 & 60,65 & 9,97827 \\
\hline Post test & 93 & 66,67 & 96,00 & 86,35 & 5,68799 \\
\hline
\end{tabular}

Evaluasi dilakukan berbentuk pertanyaan tentang materi pelatihan, dimana diberikan sebelum materi pelatihan diberikan (pre test) dan setelah materi pelatihan selesai diberikan (post test). Hasil pre test dan post test ditunjukkan pada Tabel 1 berikut.

Tabel 1. Statistika deskriptif nilai pre test dan post test 
Rata-rata nilai pre test peserta adalah 60,65, dengan nilai standar deviasi mencappai 5,687999. Sementara itu, rata-rata post test sebesar 86,35, dengan standar deviasi sebesar 9,97827. Nilai yang diperoleh menunjukkan indikasi terjadinya peningkatan kompetensi peserta pelatihan sebelum dan sesudah mengikuti pelatihan. Hasil pre test dan post test ini selanjutnya dianalisis dengan uji t sampel berpasangan (paired sample t test) dimana persyaratan pengujian adalah data terdistribusi normal. Uji Kolmogorov-Smirnov untuk melihat normalitas data disajikan pada Tabel 2 dimana, baik nilai signifikansi pre test maupun post test lebih besar dari taraf signifikansi 0.05 . Nilai pre test $(0,121)$ dan post test $(0,168)$. Terjadi penerimaan $\mathrm{H}_{0}$ dari keragaan hasil di atas, dimana $\mathrm{H}_{0}$ adalah data tersebut telah terdistribusi secara normal. Keragaan tersebut memenuhi kecukupan syarat untuk dilakukannya pengujian hipotesis dengan paired sample t test.

Tabel 2. Hasil uji normalitas dan t berpasangan nilai pre test dan post test

\begin{tabular}{lcrrc}
\hline Indikator & \multicolumn{2}{c}{ Nilai signifikansi } & Taraf signifikansi & \multirow{2}{*}{ Kesimpulan } \\
\cline { 2 - 3 } & Pret test & Post test & & \\
\hline Uji normalitas & 0,121 & 0,168 & 0,05 & Normal \\
Uji t berpasangan & & -25.123 & 0.0000 & Signifikan \\
\hline
\end{tabular}

Hasil uji t sampel berpasangan yang dilakukan (Tabel 2) menunjukkan taraf signifikansi leiih besar dari nilai signifikansi $(0.05>0.00)$. Hal tersebut memutuskan terima $\mathrm{H}_{1}$, yang berarti terdapat perbedaan nyata antara nilai rata-rata pret test dan post test responden Pelatihan berpengaruh terhadap hasil test. Dengan kata lain, kegiatan pelatihan Dasar Fungsional Ahli Bagi Penyuluh Pertanian yang dilaksanakan di Balai Pelatihan Pertanian Jambi memberikan kontribusi dalam meningkatkan kompetensi peserta setelah menjalani pelatihan. Hal ini sejalan dengan hasil penelitian Efendy (2016) bahwa pemberian Pre-test dan Post-test dalam pembelajaran mempunyai pengaruh yang berarti terhadap hasil belajar dan hasil penelitian Suci \& Jamil (2019) yang menyimpulkan bahwa metode pelatihan yang dilaksanakan di BPP Jambi telah mampu meningkatkan kompetensi peserta pelatihan melalui instrumen nilai pre test dan post test.

\subsection{Hubungan Penilaian Prilaku Peserta Awal, Tengah dan Akhir}

Perilaku adalah suatu sikap yang muncul dari diri peserta pelatihan dalam merespon setiap kegiatan berlatih yang terjadi, menunjukkan sikapnya apakah antusias danbertanggung jawab atas kesempatan berlatih yang diberikan kepadanya. Nilai perilaku adalah akumulasi dari unsur-unsur disiplin, kepemimpinan, kerjasama, prakarsa, dan kepemimpinan yang penilaiannya dilakukan dari sesama peserta (antar peserta) dan dari widyaiswara pemberi materi. Penilaian dilakukan tiga kali yaitu tahap awal, tahap tengah, dan akhir. Tabel 3 menunjukkan bahwa rata-rata nilai perilaku responden pada tahap awal sebesar 77,72 dengan standar deviasi 1,20175, kemudian pada tahap tengah nilai perilaku naik menjadi 80,8 dengan standar deviasi 2,41025, sedangkan untuk tahap akhir naik lagi menjadi 83,69 dengan standar deviasi 3,74642. Hal tersebut adanya penanda peningkatan rata-rata kompetensi responden dari awal mengikuti latihan, pertengahan, dan akhir pelatihan.

Tabel 3. Statistika deskriptif data nilai perilaku peserta pelatihan

\begin{tabular}{lrrrrr}
\hline & N & \multicolumn{1}{c}{ Minimum } & \multicolumn{1}{c}{ Maximum } & \multicolumn{1}{c}{ Mean } & \multicolumn{1}{c}{ Std.Deviation } \\
\hline Perilaku awal & 93 & 75,00 & 79,80 & 77,7243 & 1,20175 \\
Perilaku tengah & 93 & 76,75 & 87,00 & 80,8147 & 2,41025 \\
Perilaku akhir & 93 & 79,80 & 90,00 & 83,6914 & 3,74642 \\
\hline
\end{tabular}

Data perilaku awal, perilaku tengah, dan perilaku akhir tersebut kemudian dilakukan uji normalitas. Berdasarkan uji normalitas menggunakan Kolmogorov-Smirmnov menunjukkan bahwa baik nilai signifikansi perilaku awal, perilaku tengah, dan perilaku akhir lebih besar dari taraf signifikansi 0.01. Kondisi tersebut merupakan syarat cukup untuk dilakukan pengujian hipotesis dengan analisi uji t sampel berpasangan. Hasil analisi uji t sampel berpasangan (Tabel 4) menunjukkan nilai signifikansi kurang dari taraf signifikansi $(0.00<0.05)$. Hal tersebut menyimpulkan bahwa tolak $\mathrm{H}_{0}$, yang berarti terdapat perbedaan nyata antara nilai rata-rata perilaku awal dengan perilaku tengah responden, nilai rata-rata perilaku tengah dengan perilaku akhir, demikian juga dengan perilaku awal dengan perilaku tengah. Dengan kata lain, kegiatan pelatihan yang diselenggarakan di Balai Pelatihan Pertanian Jambi efektif dalam meningkatkan kompetensi dari responden sebagai peserta pelatihan setelah mengikuti 
pelatihan. Hasil ini sejalan dengan penelitian Warda Mukti (2019) menyatakan bahwa terdapat pengaruh perilaku belajar terhadap prestasi belajar.

Tabel 4. Hasil uji t sampel berpasangan penilaian perilaku

\begin{tabular}{llrr}
\hline & $\mathrm{t}$ & Df & Sig. (2-tailed) \\
\hline Perilaku awal - perilaku tengah & $-12,211$ & 92 & 0,000 \\
Perilaku tengah - perilaku akhir & $-11,598$ & 92 & 0,000 \\
Perilaku awal - perilaku akhir & $-13,855$ & 92 & 0,000 \\
\hline
\end{tabular}

\subsection{Hubungan Daily Mood, Kepuasan Berlatih, Perilaku, Post Test dan Ujian Komprehensif}

Beberapa variabel yang digunakan dalam peningkatan kompetensi responden sebagai peserta pelatihan memiliki hubungan satu dengan yang lainnya, yang meliputi dailymood, kepuasan berlatih, perilaku, post test, dan hasil ujian komprehensif. Keeratan hubungan antar variabel tersebut disajikan pada Tabel 5, dimana hubungan antara variabel satu dengan variabel lainnya adalah hubungan yang bersifat positif dan signifikan yang ditunjukkan nilai $r$ (korelasi pearson) semuanya posiitif dan nilai sig.(2-tailed) lebih kecil dari taraf signifikansi yang dipersyaratkan sebesar 0,01.

Tabel 5. Hasil uji korelasi

\begin{tabular}{|c|c|c|c|c|c|}
\hline & Daily-mood & $\begin{array}{c}\text { Kepuasan } \\
\text { berlatih }\end{array}$ & Perilaku & Post test & $\begin{array}{l}\text { Hasil ujian } \\
\text { komprehensif }\end{array}$ \\
\hline Dailymood & - & & & & \\
\hline Kepuasan berlatih & $0,305 * * *$ & & & & \\
\hline Perilaku & $0,275^{* * *}$ & $0,413 * * *$ & - & & \\
\hline Post test & $0,362 * * *$ & $0,577 * * *$ & $0,3417 * * *$ & & \\
\hline $\begin{array}{l}\text { Hasil ujian } \\
\text { komprehensif }\end{array}$ & $0,248 * * *$ & $0,429 * * *$ & $0,560 * * *$ & $0,492 * * *$ & - \\
\hline
\end{tabular}

Variabel dailymood yaitu perasaan harian responden selama mengikuti pelatihan rata-rata sebesar 2,816 termasuk kategori senang, memiliki keeratan hubungan yang positif dengan kepuasan berlatih dengan nilai korelasi pearson sebesar 0,305 . Alasan yang dapat dikemukakan adalah bila perasaan harian responden senang selama mengikuti pelatihan maka akan memberikan hasil kepuasan berlatih yang baik pula. Dailymood juga memiliki hubungan positif dengan perilaku yang ditampilkan responden selama berlatih, ini ditunjukkan dengan nilai korelasi sebesar 0,35 , artinya perasaan senang akan memberikan pengaruh positif terhadap perilaku yang meliputi disiplin, motivasi, kerjasama, dan kepemimpinan. Hasil post test dan hasil ujian komprehensif juga memiliki hubungan positif dengan dailymood dimana nilai korelasi masing masing 0,362 dan 0,248 . Artinya perasaan senang selama berlatih memerikan nilai post test dan hasil ujian komprehensif yang signifikan. Mood merupakan situasi kejiwaan (psikologi) dimana emosi terlibat namun tanpa adanya objek emosi yang terdeteksi secara nyata. Meskipun mood terbentuk sebagai variabel psikologi yang abstrak, kontribusi emosi terhadap perilaku manusia sangat penting. Hasil analisis terhadap variabel dailymood sesuai dengan hasil penelitian menunjukkan bahwa keadaan mood yang positif dan negatif memiliki implikasi terhadap perilaku manusiaHal ini sejalan dengan penelitian yang dilakukan oleh Fedorikhin dan Cole (2004) menunjukkan bahwa mood positif memiliki implikasi untuk menurunkan persepsi partisipan akan pengambilan keputusan yang beresiko. Resiko dalam hal ini adalah resiko kegagalan dalam pelatihan.

Variabel Kepuasan berlatih adalah kepuasan layanan yang dirasakan responden selama mengikuti pelatihan. Salah satu fungsi persepsi atau kesan terhadap kinerja dan harapan dapat disebut dengan kepuasan. Jika kinerja melebihi harapan maka pelanggan amat puas atau senang (Kotler 2006). Ratarata kepuasan berlatih 4,061 termasuk kategori baik, yang meliputi kepuasan pelayanan administrasi (4,042; baik), kepuasan fasilitas pelatihan (3,907; baik), dan kepuasan terhadap widyaiswara 94,234; baik). Variabel kepuasan berlatih memiliki hubungan yang positif dan signifikan dengan variabelvariabel perilaku $(r=0,413)$, post test $(r=0,577)$, dan hasil ujian komprehensif $(r=0,429)$. Dapat dikatakan bahwa responden yang merasa puas akan menghasilkan kinerja yang baik yaitu perilaku, hasil post test, dan hasil ujian komprehenshif.

Variabel perilaku yang meliputi unsur-unsur disiplin, motivasi, kerjasama, prakarsa, dan kepemimpinan responden pada tahap awal pelatihan sebessar 77,724 (baik), pada pertengahan pelatihan 
80,815 (Baik), dan pada tahap akhir pelatihan 83,69 (sangat baik). Ini mengindikasikan adanya peningkatan kompetensi dari aspek perilaku responnden. Variabel perilaku ini memiliki hubungan yang positif dan signifikan dengan variabel-variabel post test $(\mathrm{r}=0,3417)$ dan hasil ujian komprehensif $(\mathrm{r}=$ $0,560)$.

Post test adalah aktivitas menilai kembali dan terakhir terhadap materi yang sudah diberika ke peserta pada hari itu juga. Hasil post test ini dibandingkan dengan hasil pret test yang telah dilakukan sehingga akan diketahui seberapa jauh efek atau pengaruh dari pengajaran yang telah dilakukan. Hasil uji statistik korelasi pearson menunjukkan bahwa post test memiliki hubungan positif dan signifikan dengan hasil ujian komprehensif dengan nilai 0,492. Post test menggambarkan kemajuan berlatih peserta, demikian juga dengan ujian komprehensif. Kalau post test sudah diketahui terlebih dahulu bentuk evaluasinya karena sudah dimulai dengan pret test, sedangkan ujian komprehensif adalah totalitas dari pembelajaran selama pelatihan sebagai evaluasi akhir. Dengan demikian dapat dikatakan bila hasil post test baik maka hasil ujian juga akan baik.

\subsection{Faktor-Faktor yang Mempengaruhi Hasil Ujian Komprehensif}

Ujian komprehenshif adalah ujian tertulis yang meliputi keseluruhan materi yang disampaikan selama pelatihan yang diikuti responden. Faktor- faktor perasaan harian (daily mood), kepuasan berlatih (kepuasan pelayanan administrasi, kepuasan pelayanan fasilitas pelatihan, kepuasan pelayanan widyaiswara), dan perilaku (kepemimpinan, motivasi, kerjasama, prakarsa, kepemimpinan) akan mempengaruhi hasil ujian komprehensif. Tabel 6 menunjukkan bahwa semua data terdistribusi normal (Uji Kolomogorov-Smirnov lebih besar dari signifikansi 0,05), menunjukkan hubungan antara variabel dependen dan independen, tidak terjadi autokorelasi (nilai uji Durbin-Watson 1,852 lebih besar dari taraf DL dan DU, serta adanya korelasi antar variabel indpenden (uji Pearson sebesar 0,478) dan tidak terjadinya kolinearitas.

Tabel 6. Hasil uji asumsi klasik model faktor-faktor yang mempengaruhi hasil ujian komprehensif

\begin{tabular}{|c|c|c|c|c|c|c|c|}
\hline Variabel & $\begin{array}{r}\text { Uji norma } \\
\text { (Kolmo } \\
\text { Smir }\end{array}$ & $\begin{array}{l}\text { as data } \\
\text { rov- } \\
\text { ) }\end{array}$ & $\begin{array}{l}\text { Uji aut } \\
\text { (Durbin }\end{array}$ & $\begin{array}{l}\text { orelasi } \\
\text { Vatson) }\end{array}$ & $\begin{array}{l}\text { Korelasi } \\
\text { (Pearson) }\end{array}$ & Kolinea & $\mathrm{s}(V I F)$ \\
\hline Ujian & $\begin{array}{l}\text { Nilai } \\
0,152\end{array}$ & $\begin{array}{l}\text { Taraf } \\
0,05\end{array}$ & Nilai & Taraf & & Nilai & $\begin{array}{c}\text { Taraf } \\
-\end{array}$ \\
\hline Komprehensif & & & & DL 1,62 & & & \\
\hline Daily mood & 0,200 & & 1,852 & dan DU & 0,478 & 1,025 & 2 \\
\hline Perilaku & 0,313 & & & 1,71 & & 1,004 & \\
\hline Kepuasan berlatih & 0,098 & & & & & 1,023 & \\
\hline
\end{tabular}

Hasil analisis regresi linear didapat variabel-variabel daily mood, kepuasan berlatih, dan perilaku peserta secara bersama-sama memiliki hubungan yang linear dengan variabel ujian komprehensif (Tabel 8), dimana nilai $\mathrm{F}$ hitung $8,763>\mathrm{F}$ tabel $(0,05 ; 2 ; 90) 3,07$ atau nilai sig $(0,000)<\alpha(0,05)$ sehingga $\mathrm{H}_{0}$ ditolak.

Hubungan linear antara variabel dependen dan independen, selanjutnya dianalisa lagi untuk mengetahui masing-masing pengaruh variabel independen terhadap variabel dependen (hasil ujian komprehensif). Hasil uji t (Tabel 7) menunjukkan bahwa hanya nilai t hitung variabel perilaku peserta 5,505 lebih besar dari tabel $(0,025 ; 90)$ 1,980, sedangkan nilai t hitung variabel daily mood $-0,646$ dan variabel kepuasan berlatih 0,863 lebih kecil dari t tabel, sehingga dikeluarkan dari persamaa linear. Disimpulkan persamaan regresi linear yang terbentuk adalah $\mathrm{Y}=12,040+0,857 \mathrm{X}$ (perilaku peserta).

Variabel perilaku yang berpengaruh nyata terhadap hasil ujian komprehensif responden terdiri dari unsur-unsur disiplin, motivasi, kerjasama, prakarsa, dan kepemimpinan. Unsur-unsur perilaku tersebut selanjutnya diuji untuk mengetahui unsur apa yang memberikan pengaruh nyata terhadap hasil ujian komprehensif responden yang selanjutnya dapat memberikan model persamaan regresi yang lebih tepat. 
Tabel 7. Hasil estimasi factor-faktor yang mempengaruhi hasil ujian komprehensif

\begin{tabular}{lrrr} 
& Variabel & Koefisien & Uji F \\
\hline Konstanta & & 12.040 & \\
Daily mood & & -1.367 & $8.763^{* * * *}$ \\
Perilaku & & $0.857 * * *$ & 0.988 \\
Kepuasan berlatih & & & \\
\hline
\end{tabular}

Keterangan: *** signifikan pada taraf nyata $1 \%$

Hasil uji regresi (Tabel 8) menunjukkan nilai $\mathrm{F}$ hitung 6,253 lebih besar dari $\mathrm{F}$ tabel $(0,05 ; 2 ; 90)$ 3,07 , artinya terdapat hubungan linear antara variabel dependen (ujian komprehensif) dengan variabel independen perilaku (disiplin, motivasi, kerjasama, prakarsa, dan kepemimpinan).

Selanjutnya untuk melihat signifikansi konstanta dari setiap variabel independen dilakukan uji t. Hasil uji t (Tabel 11) menunjukkan variabel-variael kerjasama, prakarsa, dan kepemimpinan yang memberikan pengaruh nyata, dimana nilai t hitung 2,378 lebih besar dari tabel $(0,025 ; 90) 1,980$ (sig 0,020 $<0,05)$, sedangkan variabel-variabel disiplin, motivasi, prakarsa, dan kepemimpinan memberi pengaruh tidak nyata, sehingga dikeluarkan dari persamaan regresi linear. Persamaan regresi linear yang terbentuk adalah $\mathrm{Y}=11,530+2,378 \mathrm{X}($ kerjasama $)$. Artinya unsur kerjasama dalam memberikan pengaruh nyata terhadap hasil ujian komprehensif responden.

Tabel 8. Hasil estimasi factor-faktor yang mempengaruhi hasil ujian komprehensif

\begin{tabular}{|c|c|c|}
\hline Variabel & Koefisien & Uji F \\
\hline Konstanta & 11.530 & \\
\hline Disiplin & -0.058 & \\
\hline Motivasi & 0.085 & \\
\hline Kerjasama & $1.093 * *$ & $0.255^{2}$ \\
\hline Prakarsa & -0.634 & \\
\hline Kepemimpinan & 0.386 & \\
\hline
\end{tabular}

Keterangan: ** signifikan pada taraf nyata 5\%

Dapat dijelaskan bahwa unsur kerjasama dalam pelatihan dimaknai sebagai kemampuan seorang peserta menempatkan dirinya dan bertindak terhadap sesama peserta, widyaiswara, dan panitia dalam melakukan tindakan kerjasama sehingga pihak lain menyatakan bahwa peserta terserbut dapat bekerjasama atau tidak. Penerapan unsur kerjasama ini akan memberikan pengaruh positif terhadap responden karena jika kerjasamanya baik akan mendapatkan nilai yang baik dari peserta lainnya dan dari widyaiswara serta dari panitia. Hal ini juga selaras dengan hasil penelitian Siregar (2019) yang menyimpulkan kerjasama berpengaruh terhadap kinerja karyawan.

\section{KESIMPULAN DAN SARAN}

\subsection{Kesimpulan}

Pelatihan dasar fungsional berkontribusi terhadap peningkatan kompetensi penyuluh pertanian yang ditunjukkan dari nilai post test, nilai perilaku, dan nilai hasil ujian komprehensif. Terjadi peningkatan kompetensi responden yang ditunjukkan dari nilai pre test rata-rata 60,65 , meningkat menjadi 86,35 (nilai post test). Hasil uji t sampel berpasangan menunjukkan nilai signifikasi lebih kecil dari taraf signifikansi, artinya terjadi peningkatan kompetensi responden dari hasil pelatihan. Unsur perilaku responden selama mengikuti pelatihan terus meningkat yang ditunjukkan dari perilaku tahap awal sebesar 77,724, tahap tengah 80,815, dan tahap akhir pelatihan sebesar 83,691. Hasil uji t sampel berpasangan, baik hubungan tahap awal dengan tahap tengah, tahap tengah dengan tahap akhir, maupun tahap awal dengan tahap akhir semuanya menunjukkan nilai signifikansi yang lebih kecil dari taraf signifikansi, artinya pelatihan efektif memberikan peningkatan kompetensi perilaku responden. Variabel-variabel dailymood, kepuasan berlatih, perilaku, post test, dan hasil ujian komprehensif yang satu dengan yang lainnya mempunyai korelasi positif dan signifikan. Hasil ujian komprehensif dipengaruhi secara bersama oleh daily mood, kepuasan berlatih, dan perilaku serta memiliki hubungan linear, yang ditunjukkan dari nilai $F$ hitung $8,763>\mathrm{F}$ tabel 3,07 atau nilai sig $(0,000<0,05)$. Uji lanjut dengan uji t menunjukkan bahwa hanya variabel perilaku yang berpengaruh terhadap hasl ujian peserta (t hitung 5,505 > lebih besar dari tabel 1,980) sehingga persamaan regresi yang terbentuk adalah $\mathrm{Y}=$ $12,040+0,857 \mathrm{X}$ (perilaku peserta). 


\subsection{Saran}

Instrumen-instrumen yang digunakan dalam pelatihan dasar fungsional penyuluh pertanian yang diselenggarakan BPP Jambi harus terus digunakan terutama pre test, post test, dailymood, perilaku, dan kepuasan berlatih. Mengingat hasil ujian komprehensif paling nyata ditentukan oleh perilaku, maka instruem ini terus dipertahankan disamping memperhatikan instrumen-instrumen dailymood dan kepuasan erlatih

\section{DAFTAR PUSTAKA}

Abugu, R.O,. Chah, J.M., Nwobodo, C.A.A.N., \& Igbokwe, E.M. (2013). Agricultural extension needs of farmers in Telfairia production and marketing in Enugu State, Nigeria. Journal of Agricultural Extension, Vol. 17 (1) : 49 - 60. https://www.tandfonline.com/toc/raee20/17/2?nav=tocList

Bahua, M. (2010). Faktor-faktor yang Memengaruhi Kinerja Penyuluh Pertanian dan Dampaknya pada Perilaku Petani Jagung di Provinsi Gorontalo. [Disertasi]. Bogor:Institut Pertanian Bogor.

Balai Pelatihan Pertanian Jambi. (2019.) Rencana Strategis (Renstra) Balai Pelatihan Pertanian (BPP) Jambi 2019 - 2024. Jambi.

Dharma, S. (2005). Manajemen Kinerja: falsafah, Teori dan Penerapannya. Yogjakarta: Pustaka Pelajar

Effendy, I. (2016). Pengaruh Pemberian Pre-Test dan Post-Test Terhadap Hasil Belajar Mata Diklat Hdw.Dev.100.2.A Pada Siswa SMK Negeri 2 Lubuk Basung. Jurnal Ilmiah Pendidikan Teknik Elektro, Vol 1(2): 81-88.

Fedorikhin, A., \& Cole, C. A. (2004). Mood effects on attitudes, perceived risk and choice: Moderators and mediators. Journal of Consumer Psychology, 14(1\&2): 2-12.

Kotler, P. \& Armstrong, A, (2008). Prinsip-Prinsip Pemasaran, Edisi Keduabelas, Jilid1. Jakarta: Penerbit Erlangga.

Lailani, A., \&cJahi, A. (2006). Kinerja Penyuluh Pertanian di beberapa Kabupaten Provinsi Jawa Barat. Jurnal Penyuluhan, Vol. 2 (2) : 99 - 106.

Mondy, R, \& Noe, R. M. (2005). Human Resouce Managament. New Jersey: Pearson Prentice-Hall. Pearson Education Inc.

Pattanayak, B. (2002). Human Resource Managament, Secpnd printing, New Delhi: Prentice-Hall of India Private Limited.

Rivera, W. M. \& Qamar, M. K. (2003). Agricultural extension, rural development and the food security challenge. Rome: FAO.

Siregar, P. H. (2019). Pengaruh Kerjasama Tim Dan Kompetensi Terhadap Kinerja Perawat pada Rumah Sakit Permata Bunda Medan. [Skripsi]. Program Studi Manajemen Fakultas Ekonomi Dan Bisnis Universitas Medan Area Medan.

Sudarmanto. (2009). Kinerja danPengembangan Kompetensi SDM, Teori, Dimensi Pengukuran danImplementasi dalam Organisasi,Yogyakarta : Pustaka Pelajar.

Suci, Y. T. \& Jamil, A. S. (2019). Hubungan Tingkat Kepuasan Pelayanan dengan Keberhasilan Peserta Pelatihan Teknis bagi Penyuluh Pertanian. Jurnal Hexagro, Vol. 3(2): 47-55.

Yusuf, A. E. (2008). Pengaruh Motivasi terhadap Peningkatan Kinerja. ttp:// teknologikinerja. wordpress.com/2008/05/06/pengaruh-motivasi-terhadap-peningkatan-kinerja/. Diakses tanggal 28 Desember 2019

Warda, M. (2019). Pengaruh Perilaku Belajar Siswa Terhadap Prestasi Belajar Ipa Biologi Siswa Kelas Viii Smpn 4 Bantimurung. Jurnal Binomial, Vol 2(1). 
[Halaman ini sengaja dikosongkan] 